\title{
Trends and Prospects in Ontario's Poplar Plantation Management*
}

\section{Zsuffa, H. W. Anderson and P. Jaciw}

Ontario Ministry of Natural Resources

Forest Research Branch

Maple, Ontario

\begin{abstract}
The hybrid poplar plantation management systems and objectives, some of the problems, and the results of work to date are summarized.

Short-rotation poplar plantations are of regularly spaced traditional-size trees, intensively managed in monoculture. Silvicultural problems are associated with clonal selection, site selection and treatment, spacing, and planting stock type. The mean annual increments of best varieties have reached at 12 years of age $29 \mathrm{~m}^{3} /$ ha ( $400 \mathrm{cu}$. ft./acre).

Forest type poplar plantations are established in logged forest areas. These are less intensively managed.

Fast growing poplar and associated shade tolerant hardwoods and conifers are planted in mixed plantations (poplar polyculture) on highly variable sites. Beneficial influences are apparent on the stem quality and phenology of associated trees. Growth stimulating effects, increased site utilization and disease resistance are expected.

In mini-rotation system, average dry yields of $8 \mathrm{t} / \mathrm{ha} / \mathrm{a}$ (3.5 tons/acre/yr) or more are produced in closely-spaced, intensively-managed 1- to 3-year-old coppice plantations. Pulping tests indicate satisfactory qualities. In addition, many other uses, from petrochemical replacement to food, have potential. The management problems under study are: clonal selection, site treatments, spacing, and mechanization.
\end{abstract}

\section{Introduction}

Most current reforestation programmes are aimed at satisfying the urgent need to grow timber as quickly as possible. Poplars can make an important contribution to such programmes. They have a rapid growth rate and their wood is well suited to the expanding requirements of the fibre-based industries. Poplars can grow on "farm" land which is presently unsuited to agriculture; alternatively, they are capable of comparatively high production when established on certain types of forest sites. A further advantage is that they can be cultivated in various ways in monoculture or in association with other tree species, even farm crops.

Several poplar species grow in Ontario and constitute a significant part of the deciduous timber inventory. In the past, little attention was paid to poplar. Recently, however, the harvesting and utilization of poplar has increased markedly. Regional shortages have already developed, especially in eastern Ontario where a good market for hardwood pulp and the availability of land has resulted in a demand for "improved" poplar. At first proven clones of Ontario origin were not available, so a number of recognized euramerican poplar ( $P . \times$ euramericana (Dode) Guinier) clones were imported from Europe and tested locally for frost hardiness. At the same time, our poplar breeding work intensified and we now have selections of promising vigorous clones of Ontario origin which currently are being tested.

Poplar timber plantations were virtually nonexistent in Ontario as recently as 5 years ago. Since then, almost 400 ha (988 acres) of plantations have been established. Silvicultural methods are being developed in order to facilitate the growth of poplar in a variety of management systems and for a number of end products. These management systems and objectives, some of the problems and results of work in poplar plantations to date are discussed below.

\section{Management Systems}

Poplar plantations can be managed either in monoculture or in mixtures with other tree species (polyculture). The management level can range from intensive to extensive. The plantations are either of traditional pulpwood size trees or of densely grown smaller coppices. Such an array of plantation systems is tied to a number of silvicultural methods. However, the success of all of these depends on some common prerequisites, namely the selection of adequate soils, the selection of the appropriate poplar clones or cultivars, the control of weed competition, the choice and maintenance of the proper spacing, and pest control.

\section{Short-Rotation Poplar Plantations}

These are plantations of regularly-spaced, traditional-size trees, established with selected stock on prepared sites. Fast growth and the production of either pulpwood or high quality (veneer) timber is the objective. Pulpwood plantations are established with unrooted cuttings, at 2.7 and $3.0 \mathrm{~m}$ (9 and $10 \mathrm{ft}$.) spacings. The rotation will be approximately 10 years and the second harvest will use coppice regrowth. Veneer plantations are established with rooted stock, in wide spacings ( 4.6 to $6.4 \mathrm{~m}$, or 15 to $21 \mathrm{ft}$.) and aimed at $20-30$ year rotation.

Short-rotation poplar plantations constitute the most widely-used and studied system in southern Ontario. Present silvicultural problems fall into the following categories: (1) clonal selection, (2) site selection and treatment, (3) spacing, and (4) planting stock type.

Poplar clones vary in their growth characteristics and site requirements (Zsuffa 1975, 1976). The basic differences in performance are due to species origin. However, considerable clonal variation 
occurs even within each species. In trials, at ages from 1 to 5 years, some clones of the same species origin varied in height growth by as much as $100 \%$, while clones of different species origin differed by as much as $400 \%$. Some clones grew relatively well on a number of sites, while others were very selective. Clonal selection, therefore, decisively influences the success of management.

Soil quality and weed competition greatly influence the early growth of trees in plantations. A survey of 15 clonal trials in southern Ontario showed a striking difference in the performance of the best clones under favourable and unfavourable site conditions (Fig. 1). Further, dense ground vegetation badly suppressed the growth of young trees (Fig. 2). Unfavourable site conditions often resulted also in diseases such as Cytospora canker, and "brown-spot" canker, and tree defects such as sun scalds or frost-cracks, in addition to poor growth.

Weed control has been tried with (a) pre-planting and planting time treatments, and (b) continued post-planting treatments. Results show that weed problems tend to be compounded, rather than alleviated, by short-term cultivation, and that it is imperative to continue with follow-up treatments. Combinations of mechanical and chemical treatments of pre-emergent and systemic herbicides are being tried and promise effective weed control coupled with improved growth of poplar.

Spacings for intensively managed clonal plantations are chosen to allow the optimum growth of trees to the desired size and to maximize yield ensuring that the site is fully utilized. Spacings have little apparent effect on very early growth of trees. However, data from experimental clonal

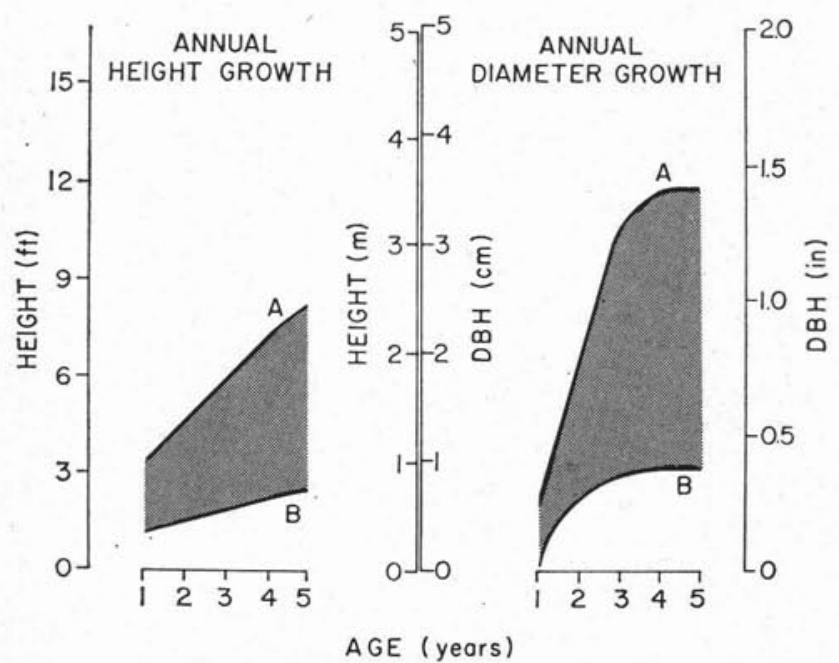

Fig. 1. The growth of hybrid poplar in field trials in southern Ontario. Average approximate values for best performing clones in 15 trials, at $3 \times 3$ $\mathrm{m}$ (10 x $10 \mathrm{ft}$.) spacing. A) Favourable conditions - fresh, aerated sand to clay loams, $\mathrm{pH}$ 5.8 to 7.6 , adequate weed control; B); Unfavourable conditions - severe limitations due to acidity, infertility, draught, poor drainage, or heavy weed competition. plantations established at spacings ranging from $1.8 \times 3.7 \mathrm{~m}(6 \times 12 \mathrm{ft}$.) to $6.1 \times 6.1 \mathrm{~m}(20 \times 20 \mathrm{ft}$. $)$ indicate that after the 4th year the closer spacings significantly restrict diameter growth of the trees (Fig. 3), although height development appears to be unaffected.

The choice of planting stock type is related to economics and the goals of management: i.e. the cost of producing, transporting and planting each type of stock has to be balanced against its subsequent survival, growth and tree quality. Trials have been conducted with the following types of stock: (a) rooted cuttings (one-year-old with stem, and one-or two-year-old decapitated), and (b) unrooted cuttings, either severed oneor two-year-old complete stems or sections of stems from 15.2 to $50.8 \mathrm{~cm}$ ( 6 to 20 in.) long.

Rooted stock survives better than unrooted stock and is recommended for widely spaced plantations in which every tree is important. However the survival of unrooted cuttings measuring $25.4 \mathrm{~cm}$ (10 in.) or more is usually above $80 \%$ when clones of good rooting ability are used on suitable sites, and is satisfactory for dense pulpwood plantations. Poorer survival is characteristic of short cuttings $(<25 \mathrm{~cm})$.

The initial size above ground of either the rooted stock with stem or the unrooted severed complete stem is usually 0.9 to $1.8 \mathrm{~m}$ ( 3 to $6 \mathrm{ft}$.).

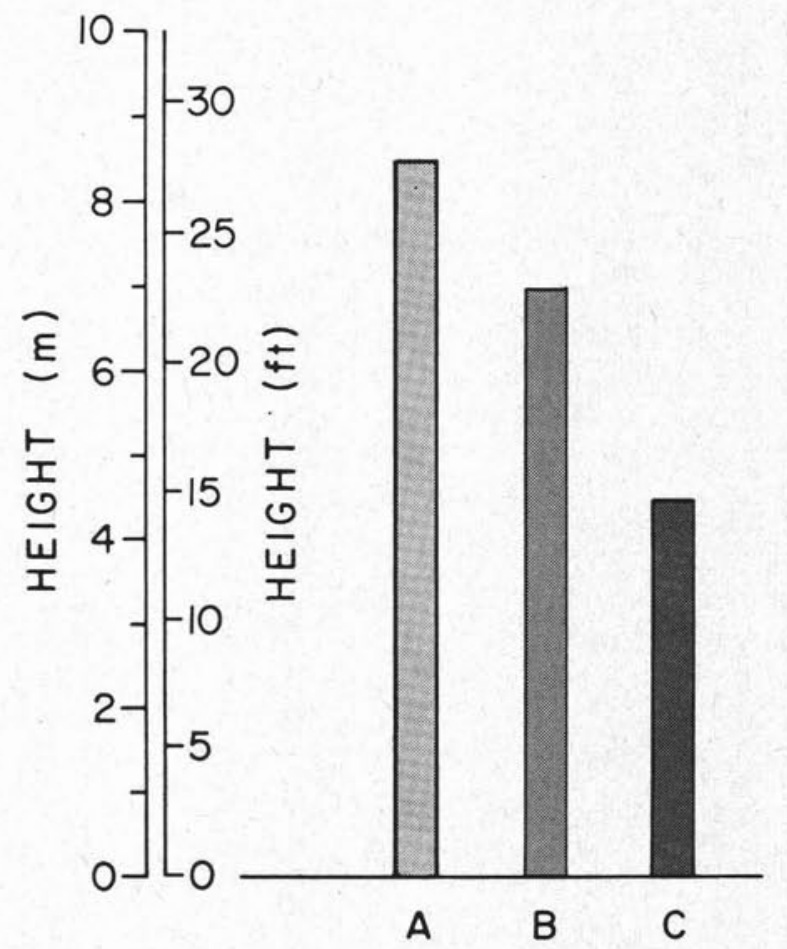

Fig. 2. The influence of preplanting site treatment and subsequent weed control on growth of $P$. $x$ euramericana clones. Five-year heights, mean values for clones "I-45/51", "Baden 431", "Blanc du Poitou", grown in comparable spacings. A) Soil completely prepared and re-cultivated every season; B) Soil completely prepared and sprayed with herbicides at planting time; C) Unprepared soil (sod), sprayed with herbicides 1 st and 2nd seasons. 
Unrooted section cuttings and decapitated rooted cuttings are planted flush to the ground. Under normal growing conditions, this initial difference in the size of planting stock disappears by the 5 th year of growth (Fig. 4). However, weed competition reduces the growth of the flush planted stock more severely than of the stock with stems.

Many refinements of plantation management are still needed to realize the full growing potential of hybrid poplar. However, even imperfect silvicultural techniques have provided encouraging results. The best hydrid poplar varieties in plantation trials in southern Ontario grew to $12.5 \mathrm{~m} \mathrm{(41}$ $\mathrm{ft}$.$) in height and to 16.5 \mathrm{~cm}$ (6.5 in.) in diameter at breast height (DBH) in just 7 years. At 12 years

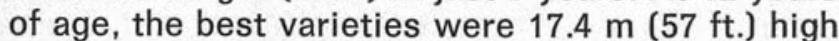
with $18.8 \mathrm{~cm}(7.4 \mathrm{in}$.) $\mathrm{DBH}$. The best mean annual increments (MAI) were $8 \mathrm{~m}^{3} /$ ha (100 cu.ft./acre) at age 7 , and $29 \mathrm{~m}^{3} /$ ha ( 400 cu.ft./acre) at 12 years. These values are excellent compared to the MAI of native aspen stands in Ontario, which even on site class I reach a maximum of only $6.3 \mathrm{~m}^{3} / \mathrm{ha}$ (90 cu.ft./acre) and then only by 50 years of age (Plonski 1960).

\section{Forest Type Poplar plantations}

Forest type plantations of poplar are less intensively managed and can be established in conditions which do not allow complete soil cultivation and weed control. Such are the conditions in logged forest areas and on some wetlands and stony sites.

Balsam poplar (Tacamahaca Spach) hybrids and aspens (Leuce L) are usually less demanding in

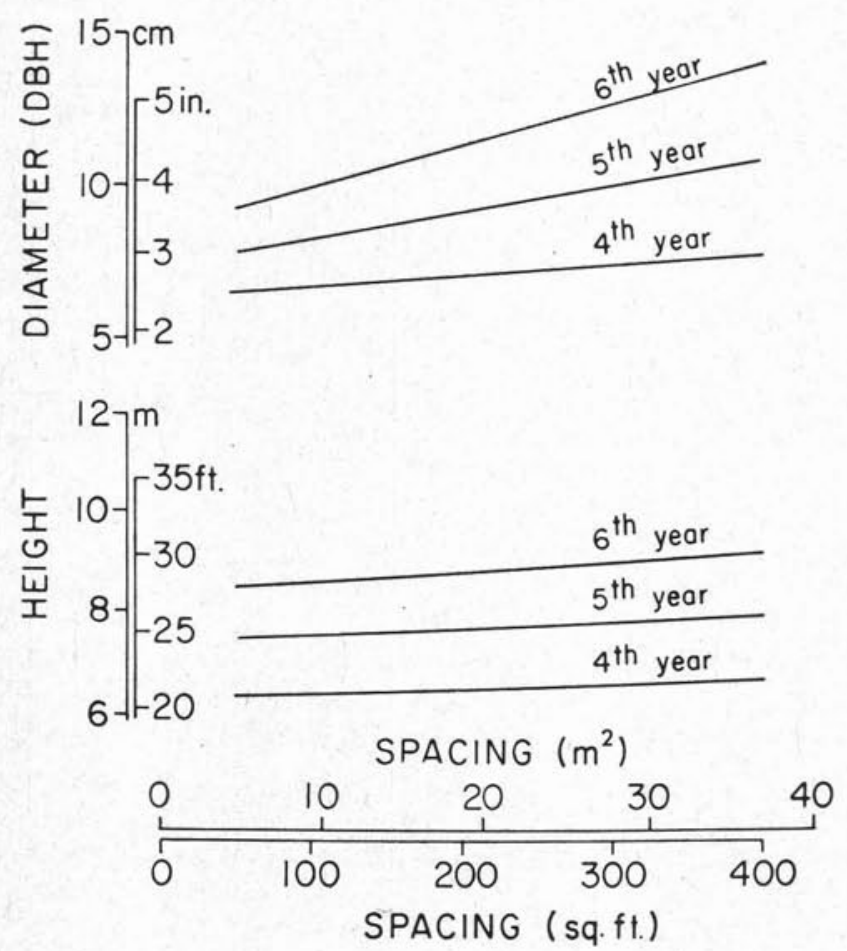

Fig. 3. The influence of spacing on the diameter and height growth of trees at 4,5, and 6-years of age. Average approximate values for the best 3 clones in each of 6 similarly managed clonal trials. their site requirements than cottonwoods ( $\mathrm{A}$ igeiros Duby). Thus, the former two are likely better for forest type plantations, although parentage and clonal choice still remains very critical for successful growth.

Rooted planting stock, either seedling or rooted cuttings, are normally used for forest type poplar plantations. Some site preparation is important for the establishment and initial growth of the planted stock. Mechanical site cultivation in furrows or in patches and chemical weed control are suitable. Generally, the trees are set out at a closer spacing than in intensively managed plantations to compensate for the likelihood of higher mortality.

We have little experience with forest type poplar plantations. Initial small scale trials in Kirkland Lake District failed because of poor stock selection and severe weed competition. Recent production trials in Huntsville and Espanola Districts show more promise. While we do not have growth figures yet, rotations longer than in intensively managed plantations (probably from 20 to 40 years) can be expected.

\section{Poplar Polyculture}

The concept of managing poplar as a nurse crop in plantations of mixed composition is being developed for some highly variable sites in southern Ontario where it may significantly contribute to quality timber and gross fibre production.

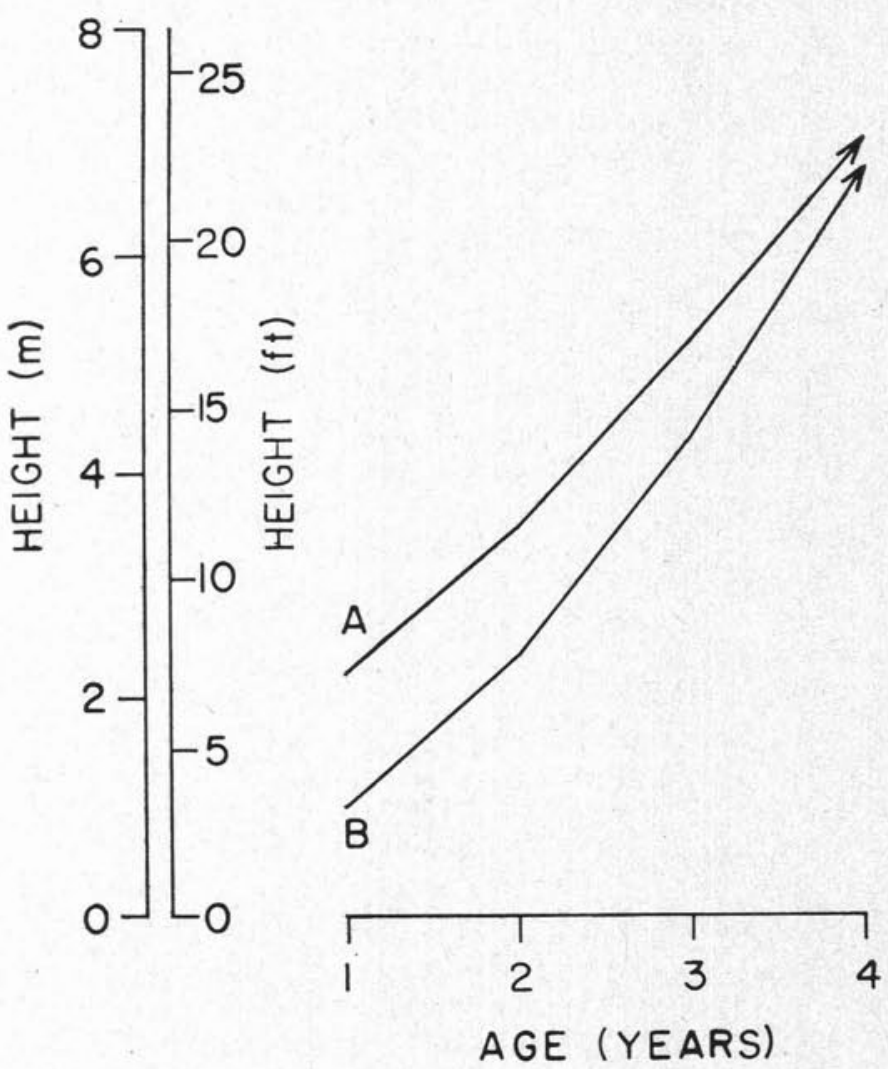

Fig. 4. The height growth of stock with stem $(A)$ and flush-planted stock (B) in favourable growing conditions. Average approximate values from 3 similarly managed clonal trials. 
Poplars are pioneer species, capable of colonizing exposed, non-forested areas. Studies of succession indicate that poplar stands act as early stages of more stable coniferous or hardwood ecosystems (Bartos 1973). Allelopathic influences of cottonwoods grown in combinations with a number of broadleaf and conifer species have been reported. Laboratory and field experiments have demonstrated both the growth-stimulating and suppressing effects of specific mixed wood associations involving poplar (Horn 1975). Mixed plantings involving poplar result in increased disease resistance, site utilization and timber quality (Kolesnichenko and Chumakov 1973). In compatible mixtures, the height and diameter growth of poplar and/or associated species may exceed those of pure controls by $30 \%$ or more. Mixed wood plantations will also yield two principal harvests, initially of the fast-growing poplar, followed by the harvest of trees of intermediate or high shade tolerance such as sugar maple (Acer saccharum Marsh), yellow birch (Betula alleghaniensis (Brit) Ashe) white ash (Fraxinus Americana L) basswood (Tilia americana L), european alder (Alnus glutinosa (L) Gaertn), oaks (Quercus L) and to some extent black walnut (Juglans nigra L). The intermediate poplar harvests, early in the rotation, will significantly defray the cost of intensive management practices required for growing quality hardwoods (Jaciw 1974).

We are studying a number of poplar varieties in the pioneer role and several hardwoods and conifers as the nursed species. Aspects being considered are (1) site evaluation, (2) plantation establishment, and (3) mutual effects of associated species. Trials are conducted on upland sites in southern Ontario, mainly on loamy soil types, varying in elevation from $244-518 \mathrm{~m}$ ( 800 to $1700 \mathrm{ft}$.) above sea level (ASL). The experimental plantations are relatively young. To date, observations have been made mainly on the poplar component (Leuce and P. x euramericana varieties).

Tests of young plantings of mixed composition indicate the influence of stresses associated with elevation and soil conditions. A survey of a $P . x$ euramericana clonal test on fresh sandy loam at $518 \mathrm{~m}$ (1700 ft.) ASL, at 6-years of age showed disease symptoms on most clones with some clones being completely healthy. This happened after initial 3-years of vigorous growth at which time adverse environmental conditions perhaps weakened the trees. In another trial, established at a comparatively low elevation of 293 m (950 $\mathrm{ft}$.) ASL on Tioga sands (Hoffman et al, 1964), inadequate soil conditions appeared to be the overriding factor responsible for high mortality and poor growth of $P . \times$ euramericana poplar.

Several- species combinations have been in vestigated for compatibility and overall performance at several spacings. Reasonable arrangements were of either $3.0 \times 6.1 \mathrm{~m}(10 \times 20 \mathrm{ft}$.) or

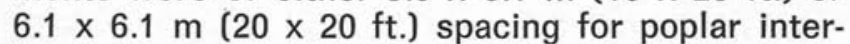

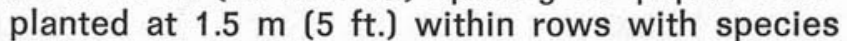
of high shade tolerance, such as sugar maple, and between rows with one or several tolerant or semi-tolerant species. This resulted in stock densities of 4440 trees/ha (1800 trees/acre). Such stocking density is desirable in view of mixed species composition and differential site utilization, allowances for mortality, quality selection and early harvests of poplar.

At this early stage, mutual influences of poplar and associated species already became apparent on the stem quality and phenology of interplanted trees. For instance, at Stratford, rapidly growing poplar protected walnut from serious hail damage (July 1975) and considerably reduced diebacks, forking and deformities of the trees (Jaciw 1974). At Flesherton, the inter-planted red oak (Quercus rubra L) developed good form and terminal dominance. It was characteristically finely branched and free of insects, infections and defoliation. The open grown control trees showed considerably higher vigour, but this was frequently offset by the formation of multiple stems, forking, sunscald injuries and fungal infections. Oak in monoculture leafed out two weeks in the spring and lost its foliage earlier in the fall then did oak grown with poplar. No phytotoxic effects were observed at this time among the tested tree species.

\section{Minirotation Poplar Plantations}

The production of large quantities of fibre in closely-spaced, intensively managed coppice plantations on one- to three-year rotation is often referred to as "minirotation forestry" (Schreiner 1970) or "poplar farming" (Anderson and Zsuffa 1977). The usual objective is to produce very high biomass yields of relatively small but usable plant material in comparatively small areas and short intervals of time, repeatedly.

High yields are promoted by relatively expensive cultural treatments such as cultivation, weed control, fertilization and perhaps even irrigation. However, these costs tend to be offset by the short investment periods ( 1 to 3 years) and the reliance upon re-sprouting, avoiding the costs of reestablishment at each operation. Other advantages arise from minimum area requirement, and from complete mechanization of management and harvesting. Naturally, best returns can be expected when high yielding clones are planted on relatively rich, accessible sites.

The management system employed to date is characterized by complete site treatment, use of $25.4 \mathrm{~cm}$ (10 in.) long unrooted cutting-stock, and $0.3 \times 0.9 \mathrm{~m}(1 \times 3 \mathrm{ft}$.) spacing. The harvesting consists of cutting all sprouts close to the ground level, whence they resprout to form the next crop.

Experiments with "minirotation" poplar were started in 1970 in Ontario. Since 1975, management trials have been continually established in eastern Ontario. The management problems under current study involve (1) clonal selection, (2) site treatments, (3) spacing, and (4) mechanization.

Proper clonal selection is of utmost significance. Growing potential, growth characteristics, site tolerance, growing space requirements, stool longevity and the quality of biomass produced are 
important variables which are under considerable genetic control and lend themselves to clonal selection. The observed differences in biomass production among frost-hardy clones were as much as 4-fold (Anderson and Zsuffa 1975, 1977. Clonal variation in specific gravity and fibre length was as high as $50 \%$, and the values were very consistent within any clone (Anderson and Zsuffa 1975).

Site treatments are very important. Minirotation poplar requires all of the cultural investments of conventional farming if maximum yields are to be realized. Fig. 5 illustrates the effect of cultural treatments on the seasonal biomass production of $P$. x euramericana cl. I-45/51 on 3 different sites. While intrinsic site effects cannot be ignored, the large differences in yield are ascribed primarily to treatment intensity.

Spacing is one of the most important factors affecting growth rate and choice of rotation length. Table 1 demonstrates the inter-action of growing space and time on the yield of clone $1-45 / 51$. It can be seen that over 1- and 2-year periods the highest yields are attained at $0.3 \times 0.9 \mathrm{~m}$ spacing. It appears that wider spacings do not produce efficiently until the site is fully occupied. In fact, it is likely that optimum spacing for annual harvests is less than $0.3 \times 0.9 \mathrm{~m}$. Yields at $0.3 \times 0.9 \mathrm{~m}$ spacing are better over a single 2-year period than over two 1-year rotations. However, there are no such advantages at wider spacings, except to increase individual tree size which may have a quality benefit (Anderson and Zsuffa 1975).

The first plantations were established and harvested manually, at a prohibitive cost. Mechanical tree planters have been adapted successfully since then and harvesters are currently being developed and tested.

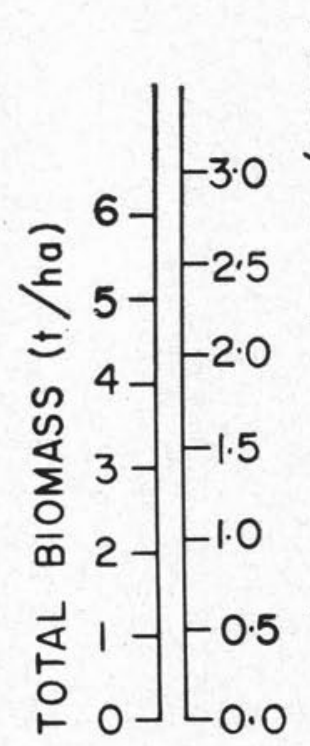

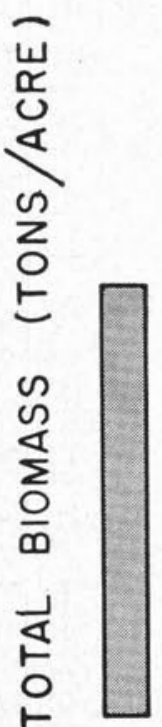

A
B

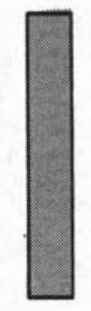

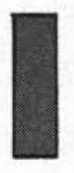

C
Fig. 5. Total oven-dry biomass production in 1st year of $P$. x euramericana cl. $1-45-/ 51$ in 3 differently managed plantations, at $0.3 \times 0.9(1 \times 3 \mathrm{ft}$. $)$ spacing. A) Kemptville nursery, cultivated, fertilized, irrigated; B) Orono nursery, some cultivation, fertilized; C) Limerick forest, no treatments.
Table 1 - Coppice yield over a variety of spacings and rotations showing total fresh biomass of wood and bark (toliage excluded) of $P$. x euramericana cl. I-45/51.

\begin{tabular}{|c|c|c|c|c|}
\hline \multirow{2}{*}{\multicolumn{2}{|c|}{ Treatment }} & \multicolumn{3}{|c|}{ Year of harvest } \\
\hline & & 1973 & 1974 & 1975 \\
\hline Spacing (m) & Rotation (yr.) & \multicolumn{3}{|c|}{ tonnes per hectare } \\
\hline $0.3 \times 0.9$ & $\begin{array}{l}1 \\
2\end{array}$ & 10.42 & $\begin{array}{l}11.98 \\
30.06\end{array}$ & 10.87 \\
\hline $0.3 \times 2.4$ & $\begin{array}{l}1 \\
2 \\
3\end{array}$ & $\begin{array}{r}6.59 \\
-\end{array}$ & $\begin{array}{r}7.03 \\
14.92 \\
\end{array}$ & $\begin{array}{r}6.35 \\
21 . \overline{97}\end{array}$ \\
\hline $0.6 \times 2.4$ & $\begin{array}{l}2 \\
3\end{array}$ & $=$ & 9.59 & $20 . \overline{93}$ \\
\hline $1.2 \times 2.4$ & 3 & - & - & 15.11 \\
\hline
\end{tabular}

Much of the economic advantage of the minirotation system derives from resprouting (selfregeneration) characteristics. We have found relatively small overall changes $(8 \% \pm)$ in yield of a variety of clones in 6 subsequent harvests over an 8 -year period. The best clones are still growing as much as 3.7 and $2.4 \mathrm{~m} \mathrm{(12} \mathrm{ft.} \mathrm{and} 8 \mathrm{ft}$.) in height in first and second growing seasons. We expect that at least five 2-year harvests are possible with suitable clones without significant change in benefit-cost relationship between current yield and reestablishment expense.

A number of agencies have tested the fibreproduction rates in minirotation systems for a variety of species, often with remarkable results (Heilman et al, 1972, DeBell 1972, Smith and DeBell 1973). In Ontario, preliminary estimates of leafless oven-dry yield of better $P$ x euramericana clones grown under intensive cultural conditions at $0.3 \times 0.9 \mathrm{~m}$ spacing ranged from 14 to $21 \mathrm{t} / \mathrm{ha} / \mathrm{a}$ (6-9 tons/acre/yr) (Zufa and Balatinecz 1971, Anderson and Zsuffa 1975). On a variety of site conditions, given minimum (but adequate) weed control and fertilization, dry yields have been consistently equal to or more than $8 \mathrm{t} / \mathrm{ha} / \mathrm{a}$ ( 3.5 tons/ acre/yr) for clone $1-45 / 51$. It is realistically expected that dry yields from 10 to $15 \mathrm{t} / \mathrm{ha} / \mathrm{a}$ (5-7 tons/acre/yr) are possible under proper management.

Pulping ${ }^{1}$ tests indicated that one- and two-yearold materials had significant paper-making qualities and could be used as a component in pulpwood furnish, despite the fact that bark contributes about $30 \%$ and $20 \%$ of the green volume of onetwo-year-old stem wood respectively.

Very many other potential uses of total poplar biomass (wood, bark and foliage), exist, ranging from petrochemical replacement to cattle feed, and these are being studied. Fig. 6 illustrates the tissue composition (by weight) of three hybrid poplar clones sampled in early September. Each of the component tissues can contribute to usable products. For example, leaf and unlignified tissues, which comprise from 30 to $46 \%$ of dry biomass, are a good source of high quality protein (Anderson and Zsuffa 1977). Efficient methods of extraction from leaf juice are being developed and

1Bryce and Temler, Domtar, Senneville Lab., report on file. 


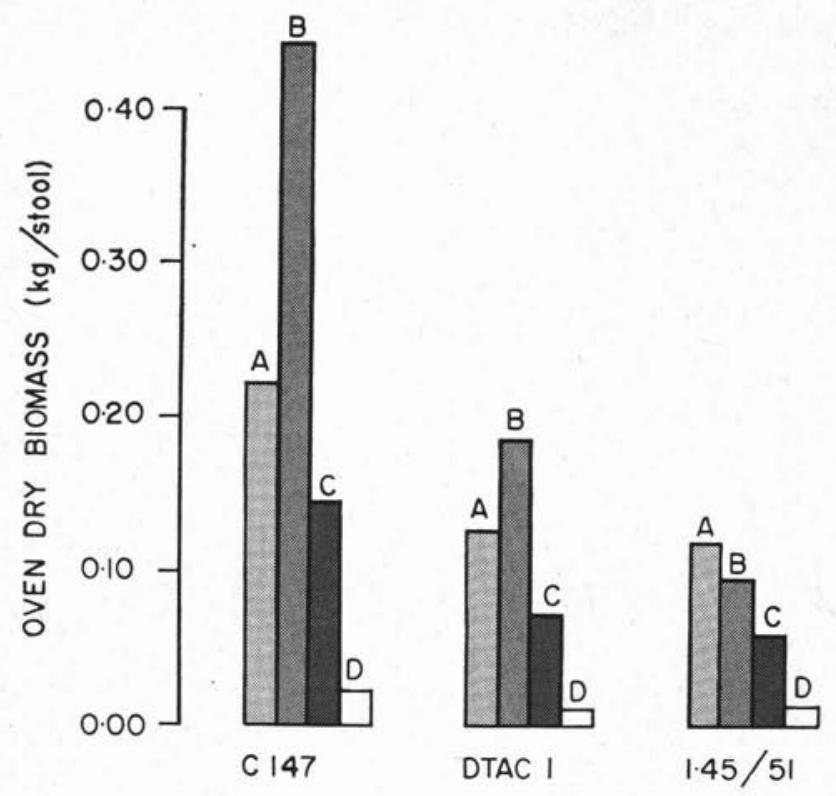

Fig. 6. One-year tissue production from resprouting stools sampled in September, growing at $0.5 \mathrm{x}$ $1.2 \mathrm{~m}$ (1.5 x $4 \mathrm{ft}$.) spacing. Clones: $C-147-P$. canescens cl. "Ingollstadt 9B", DTacl - P. deltoides $\mathrm{x}$ berolinesis $\mathrm{cl}$. NE32, and $1-45 / 51-P . \times$ euramericana cl. I-45-/51. Tissues: A) leaf; B) wood; C) bark; D) unlignified (soft) terminal sprout growth.

the residue can be used as cattle fodder or as a food base for single cell protein production. Bark also contains considerable amounts of protein and could be used similarly if removed from the wood in preparation for pulping.

Leaves of hybrid poplar exhibit high digestibility and may also be used directly as cattle fodder after ensilage. Hybrid poplar wood is relatively low in lignin and lends itself to single cell protein production and as cattle feed following suitable pretreatment. The xylose content of this juvenile wood is high and it could be used advantageously in the production of xylitol and furfural.

Minirotation poplar shows great promise of large and versatile yield, perhaps giving us the ultimate in forest practice. But this production is sensitive to the growing conditions, including cultural treatment, and the realization of this ultimate yield will also require the ultimate in silvicultural skill and husbandry.

\section{Acknowledgment}

We acknowledge the enthusiastic cooperation and assistance of many tree farmers in southern Ontario and of many forest and nursery managers, especially in eastern Ontario, in poplar culture development.

\section{References}

Anderson, H. and L. Zsuffa. 1975. Yield and wood quality of hybrid cottonwood grown in two-year-rotation. Ontario Min. Natur. Resources. Forest Res. Rep. 101.

Anderson, H. and L. Zsuffa. 1977. Farming hybrid poplar for food and fibre. An exploratory study of the seasonal above-ground biomass. Ont. Min. Natur. Resources Forest Res. Rep. 103.

Bartos, D. L. 1973. A dynamic model of aspen succession. IUFRO Bicmass Stud., Coll. Life Agr., Univ. Maine, Orono, pp. 13-25.

DeBell, D. S. 1972. Potential productivity of dense young thickets of red alder. Crown Zellerbach, Cent. Res., Camas, Wash., Forest. Res. Note. 2.

Heilman, P. E., D. V. Peabody Jr., D. S. DeBell and R. F. Strand. 1972. A test of close-spaced, short-rotation culture of black cottonwood. Can. J. Forest Res. 2: 456-459.

Hoffman, D. W., B. C. Matthews and R. E. Wicklund. 1964. Soil survey of Dufferin County, Ontario. Rep. 38, Ontario Soil Surv., Res. Branch, Dep. Agr. and Ontario Agr. Coll.

Horn, H. S. 1975. Forest succession. Sci. Amer. 232(5): 90-97.

Jaciw, P. 1974. Black walnut, a valuable associate in mixed hardwood plantations. In 65th Ann. Rep. Northern Nut Growers Ass.: 96-102.

Kolesnichenko, M. V. and V. V. Chumakov. 1973. Principle of selecting compatible species for establishment in mixed cultures with Canadian poplar. Lesnoe Zh 16(5): 12-16. (In Russian)

Plonski, W. L. 1960. Normal yield tables. Ontario Dep. Lands and Forests, Silvicult. Ser., Bull. 2.

Smith, J. H. G. and D. S. DeBell. 1973. Opportunities for short rotation culture and complete utilization of seven northwestern tree species. Forest Chron. 49: 31-34.

Schreiner, E. J. 1970. Mini-rotation forestry. USDA Forest Serv. Res. Paper NE-174.

Zsuffa, L. 1975. Some problems of hybrid poplar selection and management in Ontario. Forest Chron. 51(6): 240-242.

Zsuffa, L. 1976. The features and prospects of poplar breedind in Ontario, Canada. Die Holzzucht 30(1): 37-40. (In German, with English summary).

Zufa, L. and J. J. Balatinecz. 1971. Poplar fibre production in one-year-rotation - the potential of a new concept. 14th Session Int. Poplar Comm., Bucharest. FO:CIP/71/ 16. 